\title{
PEDAGOGY
}

\section{PREPARING FUTURE TEACHERS FOR FOSTERING A HUMAN ATTITUDE OF PRIMARY SCHOOL CHILDREN TOWARDS LIVING NATURE}

\author{
Anastasiia Varenychenko, \\ Assistant at the Department of Elementary education, \\ Bogdan Khmelnitsky Melitopol State Pedagogical University \\ Ukraine, Melitopol,
}

DOI: https://doi.org/10.31435/rsglobal_ws/30042019/6477

\section{ARTICLE INFO}

Received: 18 February 2019

Accepted: 24 April 2019

Published: 30 April 2019

\section{KEYWORDS}

Teacher training, environmental education, ethical education, living objects, subjective attitude development, humane attitude. \begin{abstract}
The article deals with the necessity of teacher training in order to foster a humane attitude of primary school children towards living nature. In addition, the methods of subjective attitude development to living objects have been singled out. Among them are explanations of animal (plant) responses, visualization, dramatization, environmental identification, environmental empathy, environmental reflection. In our survey, we differentiate between the following components of students towards the environment: cognitive and process, emotional and value, motivational, practical and action ones. These components have also been experimentally checked. The goal of my research is to develop the methodological tips and suggestions for future teachers related to environmental education and conservation.
\end{abstract}

Citation: Anastasiia Varenychenko. (2019) Preparing Future Teachers for Fostering a Human Attitude of Primary School Children Towards Living Nature. World Science. 4(44), Vol.3. doi: 10.31435/rsglobal_ws/30042019/6477

Copyright: (C) 2019 Anastasiia Varenychenko. This is an open-access article distributed under the terms of the Creative Commons Attribution License (CC BY). The use, distribution or reproduction in other forums is permitted, provided the original author(s) or licensor are credited and that the original publication in this journal is cited, in accordance with accepted academic practice. No use, distribution or reproduction is permitted which does not comply with these terms.

Introduction. In the modern world, the global ecological crisis, which is the result of the world outlook, consciousness and the morals of people, continues to threaten not only our environment, but also our very existence. Most people know the natural world is facing great challenges and degradation. Without a doubt, mankind must address the issue of sustainability and develop responsible attitude towards nature in future generations.

Without reservation, Ukraine remains fully committed to the implementation of sustainable development. The general goal of our educational system is to develop a scientifically and environmentally literate citizenry. Such environmental education must start in primary school. Unfortunately, the implementation of such innovations is hindered by insufficient development of environmental education in terms of theory and practice, the lack of effective educational approaches and the limited educational potential of the school lesson [1].

However, extracurricular activities are the optimal way for students to take an active role in the care and preservation of our environment by means of innovative methods and techniques. Additionally, it helps them to be responsible for their environment.

The topicality of our research is determined by the social demand in human behavior models in relation to nature. The goal of the study is to identify the pedagogical conditions for the effectiveness of the environmental and ethical education. Also, such approaches can be used to develop the methodological training for the teachers and will eventually improve the humane attitude of primary school children to living nature in extracurricular natural science activities $[2,3]$. 
On a theoretical basis, methodological support was provided for the adjustment of primary school education, and thus it will lead to harmonious interaction with wildlife. Specifically, this study examines the nature of primary student humane qualities in interaction with the nature as well as the methodical approaches. Since a methodical complex has been developed and tested, our study has a practical significance. Moreover, it advices on fostering of environmental and ethical relations with wildlife. It also includes methodical workings of the game-trip and environmental actions, which are intended to train teachers for organizing and conducting extra-curricular activities.

Research results. Current literature suggests that such problems have been investigated by many post-soviet researchers. The prerequisites for the formation of a humane attitude of man to nature, the basis of which was considered their harmonious coexistence, were investigated by A. Zakhlebny, I. Zverev, M. Kiselev, V. Chrischenko, L. Saliyev, A. Sidel'kovskii, I. Suravehina, V. Chervonetsky. We also studied some aspects and approaches to the solution of the identified problem. P. Burdeiny, M. Dudenko, S. Sovgira investigated the local lore approach. I. Pavlenko, G. Tarasenko, S. Zhupanin, L. Pechko, O. Prushkovskaya, N. Gorobets dealt with the aesthetic approach. O. Kolonkova, G. Marochko, V. Marshitska, Z. Plokhii, N. Yarysheva studied emotional value. T. Baibara, N. Bibik, O. Bida, K. Guz, V. Ilchenko, A. Stepanyuk, L. Shapoval worked on cognitive aspects of formation of ecological consciousness. I. Zharkova, N. Zhuk, A. Kryukova, N. Lysenko, G. Pustovit, N. Pustovit, V. Melash [4, 5], S. Sovgira, Miller G. T. [7], Thorpe A. [9], Nolet V. [10] developed the praxiological aspects of the humane attitude of students to the environment.

If our students are brought up in the spirit of respect toward other living beings, they might then develop the qualities to protect the rights of animals and plants, regardless of human benefits.

Certainly, primary school teachers must be concerned with developing among students the ability to be responsible for their actions, foster an ecocentric perspective, impose moral values regarding nature and acquire the practical skills needed to preserve our environment.

Such human qualities as mercy, compassion, sensitivity, kindness, goodwill, caring, charity, etc. are the keys in developing a human attitude and closely linked with the students' senses, especially at the elementary school level.

However, this might not be achieved unless subjective attitude to nature is taught through the integration of special teaching techniques and methods.

In order to raise children's human qualities in relation to nature (mercy, compassion, sensitivity, kindness, goodwill, caring, charity, etc.), the elementary school teacher should plan educational work, passing through the following stages 1) mercy; 2) positive attitude towards "bad" beings; 3) the feeling of kinship of man and nature; 4) aesthetic and spiritual perception of objects and phenomena of nature; 5) respect for any form of life; 6) humane and environmentally sound behavior; 7) prevention of cases of violence, cruelty, insensitivity to wildlife [7].

It is desirable to focus the attention of the students on the feelings in general and feelings of another living being in particular by applying new approaches. Such approaches are connected with the subjective attitude to nature objects.

1) Clarification of animal and plant responses to attention, care, indifference, cruelty, love, etc. It involves student observation. Undoubtedly, it helps children learn about how pets and their owner interact as well as plants absorb water and react to their feeding.

Students discuss the causes of aggressive behavior of homeless animals. Some videos of animal battles, training process, etc. can be demonstrated for the purpose to advice the children what they can do good (pleasant) for wildlife and what actions can harm it.

2) Visualization. Children try to imagine themselves in the place of a defenseless hungry sparrow, trampled plant, moose, which found a forest feeder with hay in winter. This will make the students understand how to rescue the living nature and how we can protect it.

3) Dramatization. You try to picture yourself as if you were a beautiful flower and make an effort to express your attitude. For example, admiring and breaking down the soil around.

4) Environmental identification. In this approach you imagine yourself to be a tree on a tourist harbor. Then you find yourself (modeling of own feelings) in a situation of regular clogging, trampling, bending, burning out of foci, etc.

5) Environmental empathy. Ask students the questions: "How would birds feel now, if children had played with their eggs?", "What are the feelings of the roses after weeding them?" Empathy can be evoked if students can associate themselves with living things. 
6) Environmental reflection. Students discuss the situation where the schoolboy brought down chestnuts with the help of a stick from a tree. And then they answer the question: "What does the tree think about him now?" This helps the students to understand how his actions can be perceived by living things with which they interact.

At the theoretical stage of our study, we found that the complex psychological structure of a humane attitude to nature should pass the following stages:

I emotional and value stage implies the internal preparation of a humane act.

II intellectual stage means external preparation of a humane act.

III behavioral and action stage shows the actual implementation.

We have found that effective pedagogical teaching tools for extra-curriculum education for younger students in order to foster goodwill in the environment are natural admiration lessons, excursions, creative hours, game-travels, organization of charity work and environmental actions. Additionally, the integrative nature of such teaching tools allow us to use sensual and emotional, artistic and creative, cognitive and analytical, active and practical ways of influencing the students' personality. In this setting, nature itself, its aesthetic, ethical, recreational, resource, recreation ground potential play a leading role as an educational factor.

The goal of my research is to develop the methodological tips for teachers concerning environmental and ethical relations of students to wildlife, in which we identified the main directions of educational work, such as: the formation of mercy, sympathy for nature; a change of the biased attitude of individuals towards plants and animals on their positive perception; the emergence of a sense of genetic unity, the merger with nature, the development of aesthetic perception of the world, the inculcation of respect, respect for any form of life; engagement in environmentally friendly, nature-loving behavior and actions; prevention of cases of cruelty and insensitivity to representatives of wildlife. We provided teachers with recommendations for the planning of appropriate pedagogical actions, the use of effective forms, methods and techniques for achieving the goal and outcome of the educational process. Consequently, it will support the cultivation of humanity of students in relation to living nature.

During the study, some extracurricular educational materials of environmental and ethical content have been developed and tested. Among them are the game plans "Road to the improvement of our little brothers", "Best help less than great sympathy", environmental actions "Planting trees will save lives", "We are in life", "Guardian nature". In the methodological training of the teacher, the balanced inclusion of accessible and interesting new methods and techniques of cognition have been introduced for primary school students. Among them are collective discussion of problems, exchange of impressions and experience of virtue in nature, didactic games, psychological exercises, quizzes, video and photo presentations, use of musical pieces, poems, fairy tales, folk wisdom, the filling of personal treasures of nature-loving affairs, collective discussion of problems. The goal of integrated classes was aimed at the enrichment of emotional and value-added education; development of environmental awareness and nature conservation skills; correction of emotional and value systems on interaction with nature; stimulating humanitarian needs and ethical motives; setting up and bringing to nature conservation and charitable actions as well as acts of care. The involvement of students to admire nature, appreciation and care for pets, concern about birds and ants, native land planting, reasonable consumption of natural resources, that is, caring interaction with the environment have been included into the methodological training of the teachers [10].

We carried out the experiment to prove the efficiency of extracurricular educational measures of environmental and ethical content for primary school children in terms of humane qualities when they are interacting with nature.

For this purpose, we have determined cognitive and analytical, emotional and value, demand and motivational as well as practical and activity components. We can observe these components and trace their change in the process of interaction of students and living things during their extracurricular activities.

The criterion for the knowledge and analysis component of a humane attitude to nature is the volume, quality, awareness and durability of environmental and ethical knowledge about nature, the ability to understand and assess the ecologically dangerous situation, the fostering of cognitive skills and actions during the nature protection activity.

The level of emotional and value component is associated with the student's ability to perceive nature as the value, brightness and character of the emotional manifestation of his feelings; the consistency of his experiences with ethical and environmental knowledge and actions. 
The need and motivational component characterizes the willingness to communicate with nature and the presence of ethical and spiritual motives for conservation [11].

The landmark for assessing the practical activity component of a humane attitude to nature is the desire of the primary school students to provide assistance to living things, the presence of specific environmental conservation skills, the manifestation of initiative and creativity in goodness for nature.

We differentiate between the four components of a humane attitude toward nature in the 3rd grade students:

I - negative and indifferent (low)

II - pragmatic and interested (average),

III - positive and interested (sufficient),

IV - humane and caring (high).

At the constatational stage of the study, only $6.9 \%$ of students identified a humane and caring type of attitude towards nature, $19.4 \%$ were positively interested, $43.1 \%$ were pragmatically interested, $31.9 \%$ showed indifference. In other words, the primary school is characterized by the average and low level of a humane attitude towards nature. In general, anthropocentric worldview and actions are dominated in primary school.

At the formative stage of the experiment, we gradually implemented the program of educational actions announced in our "Methodological suggestions on the fostering of environmental and ethical relations of primary school students with wildlife" for the development of children's positive attitude and mercy to all living beings, a sense of unity, merge with nature; involving them in the aesthetically and spiritually perception of the surrounding world; implanting the need and willingness to carry out humane and ecologically appropriate actions. Our system of extracurricular activities has been implemented into practice. Children were selected for interesting and accessible activities for correction of their emotional and value conditioning, stimulation of their spiritual needs and ethical motives during their activity in nature, the development of environmental abstraction and nature conservation skills, their engagement into ecological labor cases, charitable acts and acts of concern. In particular, the children were taught to admire and revere the nature, appreciate and care for pets, worry about birds and ants, plant greenery on their native land, use wisely our natural resources, etc.

At the control stage of our study, we found out the impact of the extra-curricular activities on a student's humane attitude toward nature. The results were obtained when students completed the task.

At the control stage the students' responses showed that there are some significant changes in their attitude to nature. Thus, the number of 3rd grade students with a pragmatic and interested attitude toward nature was $29.3 \%$, but with a negative and indifferent declined to $15.3 \%$. The percentage of children with a positive and interested attitude toward nature has grown to 37.5 , with a humane and caring one has risen up to $18.1 \%$. In our opinion, this positive tendency indicates the effectiveness of our educational materials.

The dynamics of a student's humane attitude toward nature in the 3rd grade after implementing extracurricular educational activities of environmental and ethical content are clearly represented in Fig. 1

It is clear that the group of primary students with a high and sufficient level of humanistic attitude toward nature grew by $29.3 \%$ (11.2\% and $18.1 \%$ respectively), whereas the number of students with the pragmatic and interested, negative and indifferent attitudes decreased (by $12.5 \%$ and $16.6 \%$ respectively).

As a result, it has been experimentally confirmed the efficiency of this approach.

Conclusions. Finally, the results of the study can bring some light to teaching humane qualities of primary school students. It has been testified the effectiveness of our methodical materials when the students interact with nature during their extracurricular time.

All these teaching strategies play a significant role in helping students to develop the above mentioned features and can be recommended to teachers of primary classes. Employing a variety of teaching strategies and techniques is the essential for successful teaching in primary school and should be used while training future teachers for extra-curriculum environmental natural science activities. 


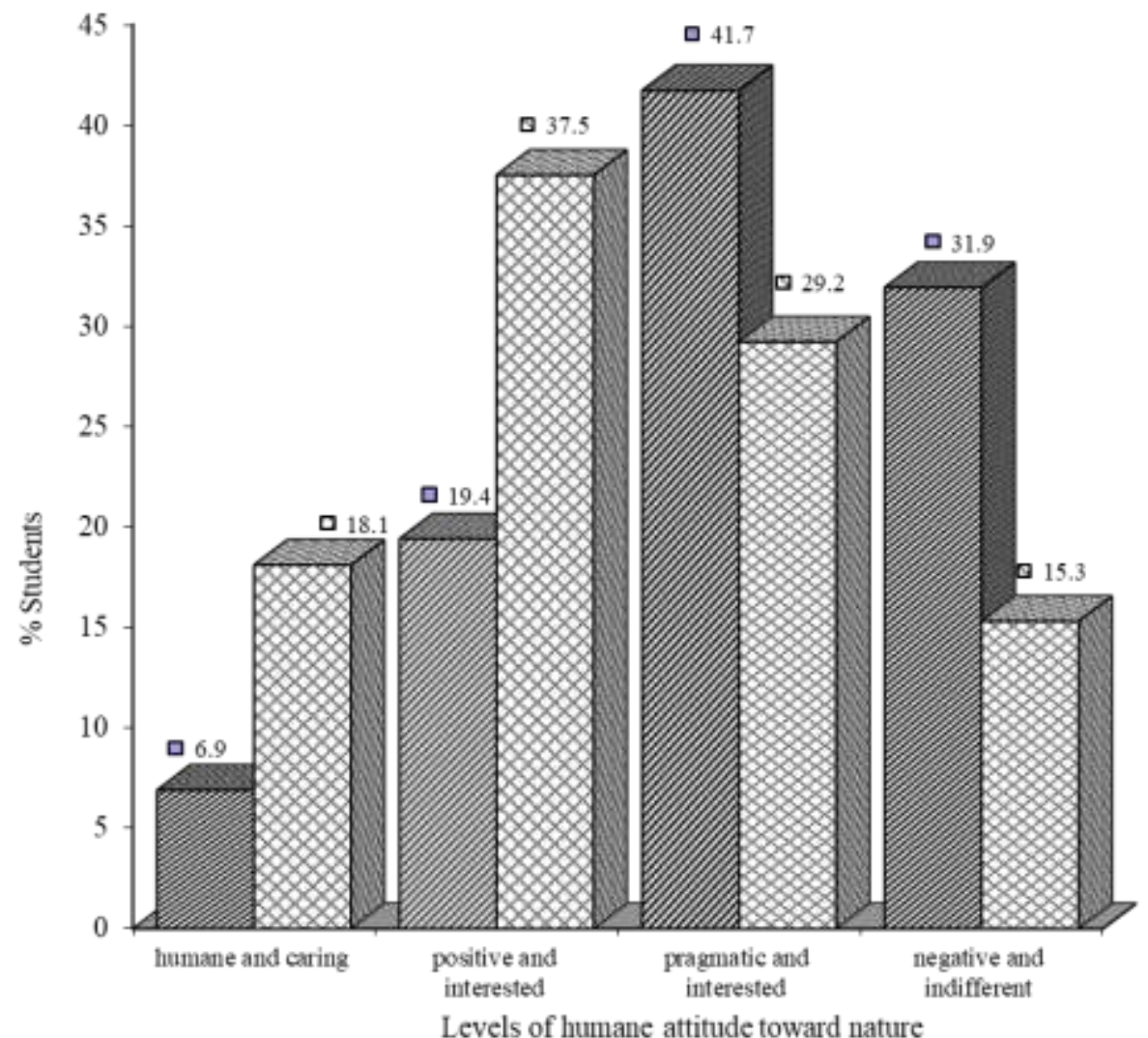

口Constatational stage

QFormative stage

Fig. 1 provides the graphic representation of different changes in student's humane attitude towards nature.

\section{REFERENCES}

1. Бойчук Ю. Д. Еколого-валеологічна культура майбутнього вчителя: теоретико-методичні основи формування : монографія / Ю. Д. Бойчук. — Суми : ВТД «Університетська книга», 2008. - 357 с.

2. Крамаренко А.М. Динаміка рівнів сформованості екологічних цінностей майбутніх учителів початкової школи / А. М. Крамаренко // Педагогіка формування творчої особистості у вищій і загальноосвітній школах : зб. наук, праць / [редкол. : T.І. Сущенко (голов. ред.) та ін.]. - Запоріжжя : КПУ, 2014. - Вип. 34 (86). - С. 198-207.

3. Маршицька В. Виховання ціннісного ставлення до природи / В. Маршицька // Початкова школа. 2012. - № 2. - С. 26-34.

4. Мелаш В. Д. Концептуальні підходи екологізації культурно-освітнього простору майбутніх педагогів / В. Д. Мелаш, А. Б. Варениченко // Проблеми підготовки сучасного вчителя: зб. наук. праць Уманського державного педагогічного університету імені Павла Тичини / ред. кол. : Побірченко Н. С. та ін. - Умань: ФОП Жовтий О.О., 2014. - вип. 10. - Ч. 1. - С. $83-88$.

5. Мелаш В. Д. Формування ціннісного ставлення молоді до природи як гарант сталого розвитку суспільства / В. Д. Мелаш, О.В.Гнатів // Науковий вісник Мелітопольського державного педагогічного університету імені Богдана Хмельницького. - Мелітополь : МДПУ. - 2013. - № 1 (10). - С. 17. - (Серія «Педагогіка»).

6. Miller G. T. Living in the Environment / G. T. Miller, S. Spoolman. - Boston, Massachusetts: Cengage, 2012. $-784 \mathrm{p}$.

7. Совгіра С.В. Екологічний світогляд майбутніх учителів: методологія, концепція, методика формування : монографія / Совгіра С. В. - Умань : Видавець «Сочінський», 2012. - 403 с.

8. Thorpe A. The Designer's Atlas of Sustainability: Charting the Conceptual Landscape through Economy, Ecology, and Culture / A. Thorpe. $-2^{\text {nd }}$ edition. - Washington D.C.: Island Press, 2007. -240 p.

9. Nolet V. Preparing Sustainability-Literate Teachers / V. Nolet // Teachers College Record. $-2009 .-$ Vol. 111, № 2. $-34 \mathrm{p}$.

10. Пруцакова О.Л. До проблеми формування екологічної компетентності школярів / О.Л. Пруцакова // Вісник Черкаського університету. - Випуск 162. - 2010. - С.135-136.

11. Пустовіт Н.А. Формування екологічної компетентності школярів: наук.-метод. посіб. / Н.А. Пустовіт, О.Л. Пруцакова, Л.Д. Руденко, О.О. Колонькова. - К. : Педагогічна думка. - 2008. - 64 с. 